\title{
Meso level Social Impact: \\ Meaningful Indicators of Community Contribution
}

\author{
Melissa Edwards, Jenny Onyx, Hazel Maxwell, Simon Darcy \\ University of Technology, Sydney
}

\begin{abstract}
Social impact measures are not widely agreed, nor implemented by third sector organisations. Meso level indicators of social impact are underdeveloped. Financialised methods such as Social Return on Investment can only account for direct outcomes of defined programs and activities. The broader societal impacts of any such activities are undervalued. This paper outlines the findings of a grounded theoretical approach to determining measures of social impact within a large Australian iconic third sector organisation. Several key factors revealed in this study are discussed in regards to their potential for attributing social impact to organisational activities outside of a program specific outcome. Based on these findings the paper concludes that the development of a tool to measure meso level organisational social impact of third sector organisations may be attainable.
\end{abstract}

\section{Introduction}

The Third Sector as a whole, and each organisation within civil society, needs to know what kind of impact it has in society at large and for its specific constituencies. It is important to know whether the organisation as a whole is making a difference to the social life of the community, and if so, what kind of difference. Sometimes it is important to know what kind of economic impact the organisation is making. However, more often what is required is a measure of the social contribution made by civil society organisations. For this, a social and not a financial measure of social impact is required. There is increasing, and increasingly, urgent demand for measures of social impact. Yet to date, there are no social impact metrics that are agreed, generic, widely relevant, with a useable metric base. Social impact is elusive, partly because it does not lend itself readily to a monetary analysis, is qualitative rather than quantitative, long term rather than short term, diffuse and multi layered rather than specific and focussed, and probably means different things in different contexts. This paper provides an empirical approach to measuring social impact within a single large Australian organisation, The Surf Life Saving Australia (SLS).

\section{Measuring Social Impact}

While there is an urgent demand for measures of social impact, to date, there are none that are agreed, generic, widely relevant, with a useable metric base. Indeed there is little agreement about what social impact is, or should represent, or whether a generic metric is 
possible. Most measures of economic impact, or economic wellbeing, are based on their financial dollar value. This is a common, easily understood, measure, and consequently is widely used to measure impact or effectiveness, or value, far beyond the actual monetary value it represents. Financial value cannot be a surrogate for health, happiness or social wellbeing.

\section{Current Measures of social impact within the third sector}

Australian Nonprofit organisations contribute to the overall functioning of the economy as demonstrated by the recent productivity commission report which estimates the sector:

'now makes up just over 4 per cent of GDP (just under $\$ 43$ billion), with nearly 5 million volunteers contributing an additional $\$ 14.6$ billion in unpaid work' (Productivity Commission 2010).

Furthermore, the recent development of the national compact signifies a federal government commitment to recognise and promote the social contribution of third sector organisations (National Compact, 2010). However, these initiatives whilst significant are inconclusive in determining a methodology for attributing the social contribution of non-profit organisations; a singular methodology remains elusive. Whilst the Productivity Commission's (2010) report identifies various methodologies for assessing the social impacts of non-profit organisations the conclusion remains that these approaches must be contextualised. The majority of existing techniques simply measure program specific outcomes but do not capture long-term or systemic social impacts. Furthermore, many activities of non-profit organisations were identified as contributing 'spillover effects' that cannot be directly attributed to proxy measures or cost-benefit analysis. This situation arises as the proxy measures used to estimate inputs such as volunteer and in-kind contribution do not account for the social capital generated as a result of these activities; that is they do not account for additional social benefits such as the social networks resulting from volunteer activity and the development of interpersonal relationships that establish a sense of community and 'belongingness', amongst others. Ironically these proxies are unable to account for the social benefits, which comprise the entirety of the social effectiveness of the third sector's contribution toward strengthening civil society. Some of these spillover effects may be attributed to the generation of social capital both within the organisation's membership and within the broader community within which the organisation operates. 
The measurement of social impact has become an important sphere of evaluation for third sector organisations. All of these have the specific aim of measuring the social impact of the organisation's programs and associated activities. That is they focus on the organisation itself and whether the organisation's programs actually meet their social objectives. There are three major frameworks for the measure of social impact within the third sector: social accounting audits (SAA), Logic Models, and Social Return on Investment (SROI). These three have been reviewed in a paper by Zappala and Lyons (2009). Of these, SROI is gaining considerable attention in Australia. It is essentially a monetising exercise, identifying a dollar value for each nominated activity or event to put in the ratio equation of investment against return. This leaves open the question of identifying the key variables to include in the equation, and the appropriate dollar value to impute to those variables. Any variable that cannot be readily given an attributed value is simply omitted from the equation.

All measures of impact within this evaluation framework have other limitations. All focus on the organisational program's social objectives. There is little awareness of wider considerations, in terms of broader social impact outside those objectives, unintended consequences, or interactive linkages with other events and programs outside the organisations immediate control. Also, because each approach depends on the particular program and organisational context, it is not possible to identify more broad based indicators of social impact, i.e. comparable data across organisations or districts is not possible. While evaluation methods are useful in measuring the outputs of specific programs, there remains a need for broader measures, ones that relate to impacts beyond the immediate and intended outcomes of specific objectives. There is a growing movement for the measurement of broad wellbeing, or 'the progress of societies' apart from economic progress (Giovannini et al. 2009). This recognises that human individual and collective wellbeing depends on more than economic or material wealth. There have been a number of international efforts to construct a global measure of wellbeing, but this has to date been unsuccessful. As Giovannini et al. note:

Over the last forty years several attempts have been made to build composite indicators or other statistical frameworks to measure progress, to overcome one of the key difficulties in the practical implementation of the different frameworks, i.e. the lack of a single metric that can bring together indicators of various phenomena expressed in different units of measurement. The European Parliament....concluded that in order to achieve sustainable development, human wealth and well-being, multidimensional indicators are needed to supplement GDP 
and to set GDP in an appropriate socio-ecological context, .....Notwithstanding some good ideas, the "Holy Grail" has not yet been found: none of the proposed frameworks has been recognised as fully satisfactory and none has emerged as a worldwide reference (Giovannini et al. 2009, p.10).

The OECD paper goes on to identify the conditions required for an adequate framework to measure societal progress. It should contain a minimum set of dimensions that taken together capture the main elements of progress, but few enough to be digestible. They need to be based on values or human ends rather than means, and they need to be meaningful to all stakeholders.

Many of the wellbeing indicators now in use are focused on more moderate targets, i.e. the wellbeing of a population in a target geographic area. This is mainly aimed at the local government level. It makes use of macro statistics as well as locally produced surveys. The aim is to obtain benchmark standards to measure various aspects of population level wellbeing over various domains. Perhaps the best of these in an Australian context is the Community Indicators Victoria, or CIV (Wiseman et al. 2006). The data framework for this rests on Indicators for five Domains and accompanying Policy areas, with several indicators derived for each policy area. This framework seeks to account for impacts of a geographical region that can be directly measured within the strategic frameworks of Local Government Areas (LGAs). The approach has been taken up and expanded in other states, most recently in City of Sydney (Partridge \& West 2010).

There are a number of limitations of this approach, apart from the difficulty of deriving effective indicators. The measures are very broad brush, usually at a macro level so that finer, disaggregated analysis is difficult. They try to capture the totality of current wellbeing regardless of the source, whether related to the state, the market, or society more broadly. This approach therefore does not provide measures of the social benefits generated by third sector organisations within the local community.

\section{Meso level indicators}

There has been little attempt to develop measures that may be more specific than the macro wellbeing indicators, but less specific than program evaluation measures. One such measure which is gaining increasing usage is the social capital scale (Onyx and Bullen, 2000). Social capital is an essential ingredient in community cohesion and well-being. Studies indicate that 
regions and groups measuring high in social capital also have a variety of positive outcomes, beyond economic advantage, such as improved health and well-being, reduced levels of crime and better educational outcomes (Putnam 2000; Halpern 2005).

Social capital, like most other social constructs, is subject to disputed definition. Social capital was defined by Putnam (1993, p. 167) as "those features of social organization, such as trust, norms and networks that can improve the efficiency of society by facilitating coordinated actions”. Woolcock and Narayan (2001) identified the multidimensional nature of social capital, which is created through various forms of joining mechanisms. These dimensions are bridging, bonding and linking. Bonding refers to the denser link of relationships common among family and friends and often visible at the community level, where individuals make regular face-to-face contact. Bridging social capital consists of weak ties, based on the impersonal relationships between strangers who share a common interest (Leonard \& Onyx 2003). Linking refers to "the relationships that people form with people in power or legitimate authorities” (Woolcock 2000, p. 19). Thus interconnected networks lie at the heart of communities, and appear to be the basic ingredient of social capital infrastructure. They are also crucial for social-capital development, which is iterative and may further enhance other relational dimensions such as trust, reciprocity, tolerance of diversity, and social agency (Onyx \& Bullen 2000; Onyx, Edwards \& Bullen 2007).

Despite the potential of social capital to measure community well being at the meso level, attempts to use such measures have been sporadic. There has been little effort to establish the validity of the social capital scale in multiple contexts, or over other domains. Measuring the levels of social capital in a given community may provide one indicator of social impact, but these are also limited in terms of what is measured. Indeed there is some critique that in principle, social impact can never be reduced to a simple metric, and to do so is dangerous, and can lead to serious abuse of the measure. Clearly, much more empirical evidence is needed to try to disentangle the various aspects of social impact, and to relate these to more direct, meso level indicators of the social impact(s) of third sector organisations within the local community.

\section{The SLS Empirical Study}

The study reported here aimed to identify those activities contributing towards SLS's social contribution to the wider community and, in so doing, to develop a potential model of social 
impact at the meso level for community based organisations in Australia. Whilst designed specifically for the SLS, the proposed research potentially has broader implications for social policy development in other third sector organisations and may prove useful in developing government policy and a National Compact.

\section{Surf Life Saving Australia: An Australian Social Icon}

SLS is a large volunteer based third sector organisation. In 2008/09 the volunteer membership consisted of 150318 participants, comprised of 57\% males and 43\% females (SLS 2009). Whilst there is a general national trend for declining volunteerism as a rate of population growth and a reduction in the number of hours volunteered by participating individuals (ABS 2007) membership at SLS has experienced steady growth. A commissioned social and economic benefit analysis uncovered the extensive contribution of SLS, but could not adequately determine the social contribution of the organisation (Allen 2005). This analysis was acknowledged as an exemplary cost-benefit analysis in the Productivity Commission report (Productivity Commission 2010), based upon measuring inputs (cost of volunteer replacements and value of replacement spending on injury and death prevention required by state and federal governments) against outcomes (such as value of lives saved and injuries prevented). In net terms, the report considered that, through the value of lives saved or serious injury averted, surf lifesaving contributed $\$ 1.4$ billion to the Australian economy in 2003-04 (Allen 2005). The value of volunteer time was estimated based upon the number of volunteer hours contributed, yet the report identified social capital contributions both within SLS and the spill-over effects of this into the broader community as one of the key strengths of SLS, although this contribution was not systematically evaluated. Similarity, the commissioners report notes that: 'the benefits to those who volunteer, including those arising through enhanced social networks, were discussed, but not valued in the study' (Productivity Commission 2010).

In the one study where Victorian volunteer members were asked of their motivations for joining the SLS (Matthews 2006), the responses related to aspects of volunteering that are difficult to measure and attribute a numerical value. The SLS strategic plan (2006) notes that volunteers report 'community involvement', the development of friendships and social networks and the enjoyment of a healthy lifestyle as a motivation for involvement. The SLS value matrix recognises a social contribution at the personal, organisational and community levels. Furthermore, after an analysis of the demographics of their membership database, SLS 
has uncovered the need to emphasise diversity as one of the core values of a socially inclusive organisation. Such recognition has fostered initiatives to encourage social inclusion in the attitudes and membership of SLS.

\section{Research design}

The study reported here represents the first stage in the development of a social impact measurement tool, and is designed to lead to the development of a larger survey tool. This first phase consisted of in-depth focus group discussion with a variety of SLS stakeholders. Both the questions and the participants were identified in consultation with SLS. Two members of the research team attended each focus group. Data was collected from eight focus groups with key SLS staff, board members and 'toes in the sand' volunteers, nationally (a total of 61 participants). There were two focus groups from each of the four states of Queensland, NSW, Victoria and South Australia. All were conducted between December 2010 and February, 2011. Numbers ranged between 3 and 11, with a mean of 8 participants in each group. Of the total, 37 were male and 24 were female. Their ages ranged from 18 to about 70, as indicated in Table 3 below.

Table 3: Breakdown of focus group participants by age group

\begin{tabular}{|l|l|}
\hline Age Group & Percentage \% \\
\hline $18-25$ & $21 \%$ \\
\hline $26-35$ & $13 \%$ \\
\hline $36-45$ & $21 \%$ \\
\hline $46-55$ & $23 \%$ \\
\hline $56-65$ & $15 \%$ \\
\hline $65-75$ & $7 \%$ \\
\hline
\end{tabular}

The questions were broad and open ended, inviting participants to reflect on what they had personally gained from involvement in the club, and what they could identify about the broader community benefits. Participants were asked to critically reflect upon those social benefits they felt they could specifically attribute to their involvement within this particular organisation. The discussion was audio recorded for later transcription and analysis, using Nvivo software to identify key themes arising from the discussion. Identification of 'nodes' or dominant themes within the focus groups was conducted through a two stage process. 
Initially, the identification of relevant nodes was undertaken independently by two researchers, and then discussed with the research team. Two researchers then independently 'blind coded' the same two transcripts using the nodes developed in the first stage and then cross-compared coding to ensure consistency between the interpretations of the nodes. At this stage the nodes were further refined and additional nodes were added to the coding scheme. Once all data had been coded using this template, all uncoded data was then analysed separately to enable the emergence of new themes that were not initially identified. This section reports the overall results of this analysis.

\section{Findings}

Figure 1 illustrates the overall structure of the main themes in terms of a 'mind map'. Some themes referred to activities internal to the organisation, others more to activities external to the organisation, while many covered both. Some referred to specific activities or processes, others to broader skills, while others referred to broader feelings or values.

Figure 1: $\quad$ Focus Group Coding Schema

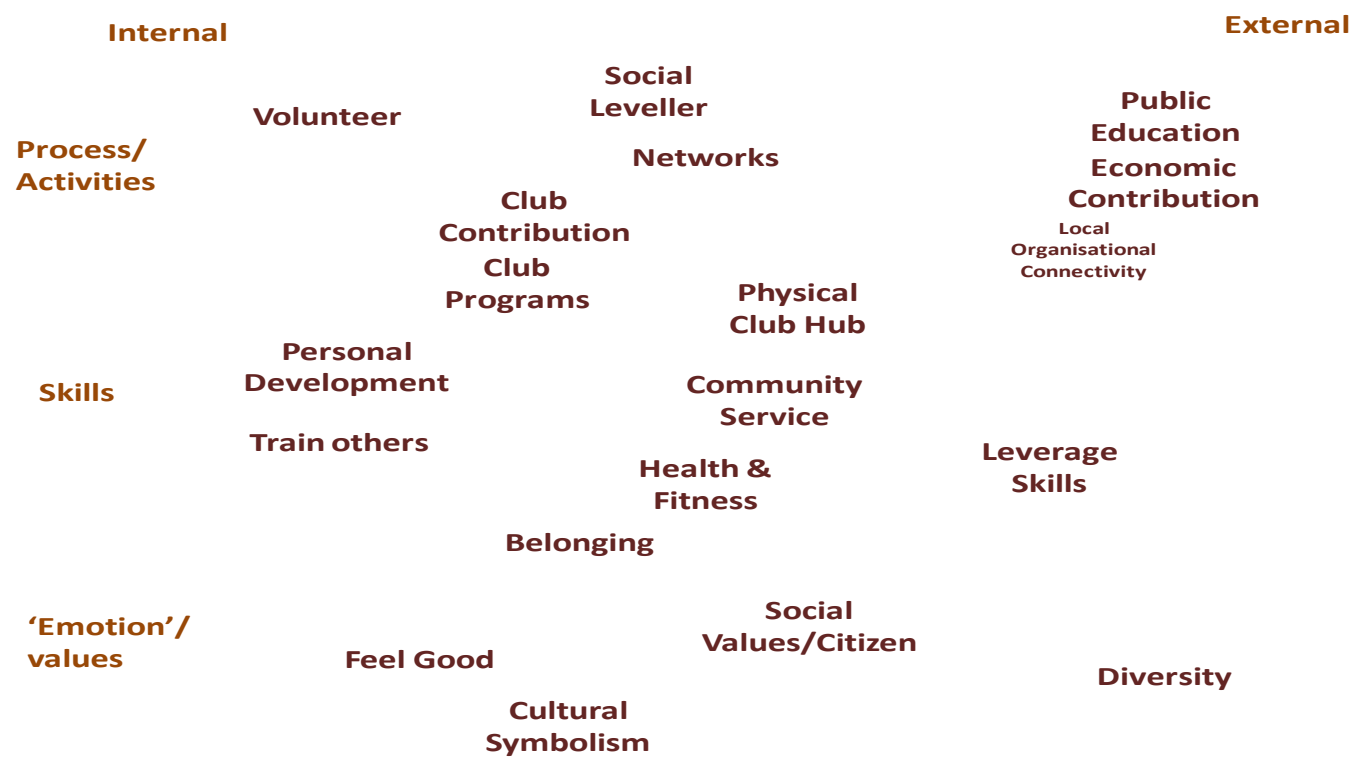

Focus groups revealed a family orientated and supportive organisational culture (engagement of whole family over life-span); the personal development of members which flow on to the wider community (e.g. social values); generic skill development among members of direct applicability to wider community (e.g. leadership skills); public education programs for the wider community (e.g. water safety); mutual assistance with other community based organisations (e.g. emergency assistance, fund-raising); facilities available as social/ training 
resource for wider community (e.g. community meetings); formal programs for disadvantaged groups (e.g. indigenous, migrants). Each of the main themes is presented for more detailed examination below with representative quotes in Table 4.

Table 4: Emergent themes and representative quotes from the focus groups

\begin{tabular}{|c|c|c|}
\hline $\begin{array}{l}\text { Emergent } \\
\text { theme }\end{array}$ & Description of theme & Representative quotes \\
\hline Belonging & $\begin{array}{l}\text { Feeling valued by others in the surf } \\
\text { club, developing common values and } \\
\text { enduring friendships }\end{array}$ & $\begin{array}{l}\text { "So you're hanging out with your } \\
\text { mates on the beach and you're } \\
\text { part of an extended big family... } \\
\text { Then you go down on the beach } \\
\text { and you're all on the beach like a } \\
\text { big family, big community" (FG1). } \\
\text { "Every person that identifies } \\
\text { themselves as a life saver } \\
\text { immediately becomes a friend" (FG } \\
\text { 7) } \\
\text { "if you are having a hard time like } \\
\text { on a weekend, you know you go to } \\
\text { the club and there's always } \\
\text { someone there to have a talk to } \\
\text { and go for a swim with" (FG6) }\end{array}$ \\
\hline $\begin{array}{l}\text { A socially } \\
\text { inclusive } \\
\text { organisation }\end{array}$ & $\begin{array}{l}\text { An organisation which treats people } \\
\text { equally and is made up of people of } \\
\text { all backgrounds, ages, both genders } \\
\text { and people from different } \\
\text { occupations and ethnicities. }\end{array}$ & $\begin{array}{l}\text { "It's a real equaliser. It doesn't } \\
\text { matter who you are or what you } \\
\text { do, you can be involved with the } \\
\text { club" (FG 2) } \\
\text { "The fact that you can go to any } \\
\text { club in Australia really and be } \\
\text { accepted for what you are. } \\
\text { Whether you are a bricklayer, a } \\
\text { politician or a doctor, it doesn't } \\
\text { make any difference" (FG 6) } \\
\text { "Most other sporting codes ... are } \\
\text { single sexed divided, whereas the } \\
\text { surf club is not" (FG 2) }\end{array}$ \\
\hline $\begin{array}{l}\text { Social and } \\
\text { Citizenship } \\
\text { Values }\end{array}$ & $\begin{array}{l}\text { Common or collective standards or } \\
\text { principles inculcated in the } \\
\text { organisation which include personal } \\
\text { reliability, commitment, } \\
\text { responsibility, pride, respect, helping } \\
\text { each other, making a difference, and } \\
\text { giving back to the community }\end{array}$ & $\begin{array}{l}\text { "The greatest thing we put back } \\
\text { into the community is community } \\
\text { minded people" (FG 3) } \\
\text { "I keep being amazed at the } \\
\text { willingness of any member of any } \\
\text { age in the club that's just willing to } \\
\text { contribute in any way or just be }\end{array}$ \\
\hline
\end{tabular}




\begin{tabular}{|c|c|c|}
\hline & & $\begin{array}{l}\text { involved in something as big as surf } \\
\text { lifesaving... They're always seen as } \\
\text { people that are contributing (FG 4) } \\
\text { "like you might go along and be } \\
\text { happy to help the football club run } \\
\text { their sausage sizzle, for example, } \\
\text { because you've already got that } \\
\text { sense of helping the community } \\
\text { through surf lifesaving" (FG 1) } \\
\text { "I used to get babysitting, because } \\
\text {... this association had recognised } \\
\text { me as responsible enough to look } \\
\text { after people on the beach. } \\
\text { Therefore it opened a broader } \\
\text { relevance" (FG 5) }\end{array}$ \\
\hline $\begin{array}{l}\text { Community } \\
\text { Service }\end{array}$ & $\begin{array}{l}\text { Voluntary service provided by Surf } \\
\text { club members in the wider } \\
\text { community outside the confines of } \\
\text { the club and beach using surf skills, } \\
\text { equipment and knowledge }\end{array}$ & $\begin{array}{l}\text { 'There was a call recently when all } \\
\text { the floods in Brisbane. We all got } \\
\text { emails, any clubby who has got } \\
\text { experience in boat skills, et cetera, } \\
\text { rubber ducky and radio skills, you } \\
\text { know could volunteer to help in the } \\
\text { flood situation in Brisbane' (FG 6) } \\
\text { I know that some clubs are } \\
\text { involved each year in the Christmas } \\
\text { Pageant. So that's not fund raising } \\
\text { at all, but it's about being in the } \\
\text { community and showing a bit of a } \\
\text { presence (FG 4) }\end{array}$ \\
\hline $\begin{array}{l}\text { Public } \\
\text { Education }\end{array}$ & $\begin{array}{l}\text { The role the organisation and its } \\
\text { members have in educating the } \\
\text { public in surf safety and associated } \\
\text { skills }\end{array}$ & $\begin{array}{l}\text { I mean we sort of apply ourselves } \\
\text { as the guardians of the beach, and } \\
\text { water safety and everything } \\
\text { around the water (FG 3) } \\
\text { "Primarily the role of it is to get out } \\
\text { there and educate them... it's } \\
\text { about, getting that education out } \\
\text { so that when they do come to the } \\
\text { beach, they have some sort of } \\
\text { understanding of what's going on } \\
\text { (FG 1) }\end{array}$ \\
\hline
\end{tabular}




\begin{tabular}{|c|c|c|}
\hline $\begin{array}{l}\text { Personal } \\
\text { Development }\end{array}$ & $\begin{array}{l}\text { The development of skills, } \\
\text { knowledge and understanding which } \\
\text { includes mentoring, leadership, } \\
\text { team work and communication } \\
\text { leading to the development of self } \\
\text { confidence and self esteem }\end{array}$ & $\begin{array}{l}\text { "They learn skills that can be used } \\
\text { for the rest of their lives" (FG 3) } \\
\text { "Learning those life skills in a fun } \\
\text { way and sometimes probably not } \\
\text { even aware they are learning life } \\
\text { skills like Nippers" (FG 6) } \\
\text { 'People come on board the } \\
\text { committee and then become } \\
\text { confident in their own ability to go } \\
\text { out and go onto other committees" } \\
\text { (FG 5) } \\
\text { "I think mentoring, like younger } \\
\text { groups through our club and it's } \\
\text { just great to teach them and watch } \\
\text { them learn and then watch them } \\
\text { develop through the club" (FG 2) }\end{array}$ \\
\hline $\begin{array}{l}\text { Leveraging } \\
\text { skills }\end{array}$ & $\begin{array}{l}\text { Members using human capital (skills, } \\
\text { training and knowledge) developed } \\
\text { through life saving in the wider } \\
\text { community particularly in work } \\
\text { places, to assist in emergency } \\
\text { situations, to gain employment, at } \\
\text { home and in leadership roles. }\end{array}$ & $\begin{array}{l}\text { "You join life saving to get skills for } \\
\text { life. It's kind of got a double } \\
\text { meaning where you get skills to } \\
\text { save lives and you get skills for } \\
\text { your own life (FG 6) } \\
\text { "There is a lot of people ... actually } \\
\text { get full time employment as a } \\
\text { result of the skills they learn } \\
\text { through life saving...many of them } \\
\text { go on to become council } \\
\text { lifeguards" (FG 6) } \\
\text { "Quite often you're the person } \\
\text { that's going to be on the spot. Car } \\
\text { accident or, as I said, somebody } \\
\text { has a heart attack somewhere. } \\
\text { That's one of the things that you're } \\
\text { taking out into the community" (FG } \\
\text { 1) }\end{array}$ \\
\hline $\begin{array}{l}\text { Connections } \\
\text { with local } \\
\text { organisations }\end{array}$ & $\begin{array}{l}\text { Linkages and partnerships with } \\
\text { other organisations in the local area } \\
\text { including sports clubs, local } \\
\text { voluntary organisations, local } \\
\text { businesses, local emergency } \\
\text { organisations, local Councils, and } \\
\text { schools. }\end{array}$ & $\begin{array}{l}\text { "All the community groups do } \\
\text { networking together at some } \\
\text { stage, so you do get the respect } \\
\text { from those groups because they } \\
\text { realise how important the surf club } \\
\text { is to the community in the smaller } \\
\text { communities. Then the Lions Club } \\
\text { might come in and sponsor or they } \\
\text { might have an award that they }\end{array}$ \\
\hline
\end{tabular}




\begin{tabular}{|c|c|c|}
\hline & & $\begin{array}{l}\text { have that they will ask if the club's } \\
\text { got someone who they'd like to } \\
\text { nominate for an award, or we've } \\
\text { got a certain amount of money } \\
\text { that we'd like to donate to your } \\
\text { club or something like that" (FG 1) } \\
\text { "I mean we have strong links to } \\
\text { local community organisations } \\
\text { such as Rotary and Lions. They get } \\
\text { involved in a lot of street fairs. If } \\
\text { you look at the Brighton Junior } \\
\text { Classic, they all come down here to } \\
\text { sort of look to help, to all raise } \\
\text { money" (FG 3) } \\
\text { "We have a very good support } \\
\text { group within the local council } \\
\text { which helps all of us because they } \\
\text { understand what we do" (FG 5) }\end{array}$ \\
\hline $\begin{array}{l}\text { Physical hub } \\
\text { for the } \\
\text { community }\end{array}$ & $\begin{array}{l}\text { The club building and associated } \\
\text { facilities as venues that the } \\
\text { community could use for meetings, } \\
\text { training, accommodation and for } \\
\text { local events. }\end{array}$ & $\begin{array}{l}\text { "Our club's got a café on it. You } \\
\text { know we've got a function area } \\
\text { outside. Glenelg's got a function } \\
\text { area upstairs that has three or four } \\
\text { nights a week available for the } \\
\text { community to come in and use } \\
\text { that" (FG3) } \\
\text { "We've given local clubs the benefit } \\
\text { of coming into the club on a } \\
\text { particular night and using the } \\
\text { venue to fundraise" (FG5) }\end{array}$ \\
\hline Volunteering & $\begin{array}{l}\text { Members 'giving back' to the } \\
\text { community }\end{array}$ & $\begin{array}{l}\text { "When you go for a job, it looks } \\
\text { better because they see that you're } \\
\text { giving something back to the } \\
\text { greater community, to the public. } \\
\text { So you're not so selfish, you're } \\
\text { thinking of other people, because } \\
\text { you're helping other people and } \\
\text { you give up your free time" (FG 1) } \\
\text { "When you come to the surf club } \\
\text { you are surf club member and you } \\
\text { are there to do services for the club } \\
\text { and for the public. I think that's } \\
\text { really important and part of the } \\
\text { volunteering situation" (FG 6) } \\
\text { "All I do now in terms of active }\end{array}$ \\
\hline
\end{tabular}




\begin{tabular}{|l|l|l|}
\hline \multirow{1}{|l|}{} & $\begin{array}{l}\text { involvement is patrolling...I think it } \\
\text { is the fact that you're doing } \\
\text { something for the community and } \\
\text { the satisfaction you get out of } \\
\text { that" (FG 7 }\end{array}$ \\
\hline
\end{tabular}

Belonging was the dominant theme. It refers to the sense that participants expressed in feeling connected through their Surf activities. Feeling connected through a community or family builds bonds between individuals which is fundamental for the development of social capital. Some of the perceived effects of this connectedness are emphasised in the participants' quotes which relate to feeling valued by others, developing common values and enduring friendships, and creating a reciprocal space for social exchange not through obligation but through shared good will. Participants cited Surf as a place to develop new and enduring lifelong friendships and as a social space where friendships could be developed and maintained. Some referred more strongly to their relationships within the club as a form of shared mateship on the beach. Associations formed through club activities form a social mateship that extends outside of the beach and clubhouse to the backyard barbeque, bringing clubbies together from various different clubhouses. Others described this mateship as a more loosely tied sense of camaraderie developed through engaging with common purpose in the club. Family was used both in the relational and the metaphorical sense of the word. In the relational sense participants mentioned how they had come into Surf through the involvement of their family members. For parents this may have been for the first time with their child as a nipper. But for others it was a case of 'growing up with Surf' with generations of family members being active and continuing members of Surf. However there was also the notion of an extended family or the club being a family oriented place.

The second most prominent theme was ‘social and citizenship values' where 'Surf' provided a connection for the development of these common values. Membership in SLS provided a bedrock of social values. These values are inculcated in everything the members do from Nippers (junior lifesaving training) onwards. They form the basis of their own personal development and participation within the club, but also provide a very strong set of citizenship values within the wider community. These values include volunteering which is discussed in terms of members 'giving back' to the community and 'making a difference in society' by 'helping people out'. The core to SLS activities involves volunteering. Focus group participants emphasised the importance of being a volunteer and providing a 
community service within the surf club. Providing voluntary service through club activities included activities such as patrolling the beach, training others, working behind the bar, cooking a barbecue or being an age group manager on the beach. Many participants identified the importance of community service within the club, in particular in relation to water safety for the public. However they did much more than that, many referred to voluntary service provided by SLS members in the wider community outside the confines of the club and beach using skills, equipment and knowledge from SLS. This occurs in emergency situations, at community events and festivals, in community education settings, through charity work and in environmental projects. For example, SLS members provided rescue and emergency assistance during natural disasters such as floods and bushfires. There were many other examples of community service in the normal course of the community calendar, or as part of wider outreach activities.

The third most frequently mentioned theme was termed 'club contribution' and encompasses the contributions individuals made in various roles to the collective operation of the club and associated activities. These roles include administration, competition, education, training, rescue, fundraising and committee roles. Whilst an intra-organisational contribution, the majority of these roles were fulfilled as volunteer hours and included some external contributions such as fundraising for other local clubs, patrolling public beaches and training and development courses offered to the public. The later was another major theme (fifth most frequently cited) and relates to the role SLS has in educating the public. This occurs across a range of settings including schools, at community events and on the beach. SLS educate the public in surf safety, surf awareness, survival skills, first aid, and surf rescue.

The development of skills, knowledge and understanding related to 'personal development' was frequently discussed by focus group participants. These skills include mentoring, leadership, team work and communication leading to the development of self confidence and self esteem. These skills were discussed in terms of developing skills to train others. The idea of leveraging skills was discussed in terms of members of SLS using personal skills as a form of human capital (skills, training and knowledge) developed through life saving out in the wider community particularly in work places, to assist in emergency situations, to gain employment, at home and in leadership roles. Sometimes the skills learned are applied directly in emergency situations out in the community and other times they were useful in work situations and in everyday life. 
As a result of being engaged in Surf activities, members referred to the benefits associated with developing internal networks, connections and relationships develop. These may lead to personal recommendations, avenue to job opportunities, and chances to participate in new activities, opportunities to learn about other communities and to develop new friendships. The development of such networks extends the social inclusivity of the club into the broader community enabling the extension of bonds into other areas of member's lives.

The respondents explained that SLS clubs do not operate in isolation from other community organisations. The focus group participants were able to identify strong connections with other community organisations in the area including sports clubs, and local voluntary organisations, local businesses, local emergency organisations, local Councils, and schools. This bridging social capital has the potential to provide the clubs with new members, sponsorship opportunities, and a chance for SLS to assist local communities. Networking involved SLS clubs working with a range of sport clubs such as golf, gymnastics, rugby, AFL, swimming, and other surf clubs. This network brings in resources and attracts new members who may participate in surf sports during the summer when they are in an off season from participation in other sports. Partnerships with Rotary and Lions clubs were often mentioned. Reciprocity was highlighted with surf clubs assisting other local organisations with fundraising by inviting them to use their club facilities or to attend their events to hold BBQs with SLS often accepting donations from these groups in return. SLS also sponsors events organised by other voluntary groups. These networks are partly about sponsorship and businesses donating to surf clubs or supporting then by providing in kind assistance. Links with local Councils were also regarded as important. The clubs maintained active networks with a range of organisations through the physical club building and its associated facilities which were described as venues that individual community members and community organisations could use. The clubs themselves were described as places for meetings, training, accommodation for SLS members, and as venues for local events.

Surf Life Saving was also described as an organisation which treated people the same irrespective of their background, described as a 'social leveller'. Gender used to be an issue in SLS given the bronzed Aussie bloke image. But that was shown to be changing, and women were much more included in SLS activities at all levels. All ages and socioeconomic status groups are included. However, despite the rhetoric of tolerance, cultural diversity 
remains an issue within SLS, illustrated by comments such as "it's traditionally Anglo-Saxon, white protestant. And we've got to change that. And it is changing, but it is changing slowly” (FG 3).

\section{Discussion}

The results from the focus groups demonstrate very clearly that SLS as a whole provides far more than a safe beach environment. It provides within club membership a nurturing environment which builds a sense of belonging and acceptance, and the basis for developing core citizenship values and life skills. In particular it instils a valuing of volunteer actions for the wider public good. These values and skills are then played out throughout the person's lifetime and in many community contexts outside the club itself. But in addition to these personal capacities, the organisation as a community entity is embedded in wider community networks and is engaged in reciprocal aid and support of other community organisations and actions. All of these things add up to an enormous ongoing social impact within the local community. By and large the impact is a positive one, enriching the lives of all citizens. There are, however some weak points, particularly in terms of reaching a more inclusive connection to ethnic minority groups. While the formal SLS organisation does indeed provide specific programs for indigenous or migrant groups, these are seldom embedded within the daily life of the local club. Nonetheless, the SLS movement is a rich and dynamic part of many communities, constantly evolving to provide a more inclusive environment of belonging.

The various themes that arise from the focus groups may be broadly clumped into larger categories or factors and these factors may have more general relevance, beyond the specific organisation of SLS. In the first instance, the strongest theme was one of Belonging, which is developing a strong sense of identity based on club activities. This initial identity leads to potentially strong personal development, including the development of citizenship values and a sense of the importance of serving others, working in a team and administering and organising club activities. Strong internal networks of mutual support suggest the development of strong bonding social capital. The club programs in turn produced increasing levels of human capital in the form of increased skills and knowledge base. This growing stock of human capital was then made available in various forms to the wider community, thus increasing the human and social benefit to that wider community. Finally, the club developed a variety of bridging links within the wider community, both at an individual and 
at an organisational level, suggesting the development of bridging social capital within the local community and beyond. All of these outcomes represent a form of social impact, as modelled in Figure 2. As suggested by the model, the process begins at an individual and club level. Strong networks of mutual support and the immediate practices of lifesaving and team work then generate broader impacts for the individual and the club. Ultimately the benefits of these values and practices extend outwards to embrace the wider community. However, these developments should not be seen as following a linear causal path. Indeed social capital itself is iterative in the sense that the resulting action of networks reinvigorates and enriches the initial forms of trust, agency and social connectedness.

Figure 2: Modelling social impact

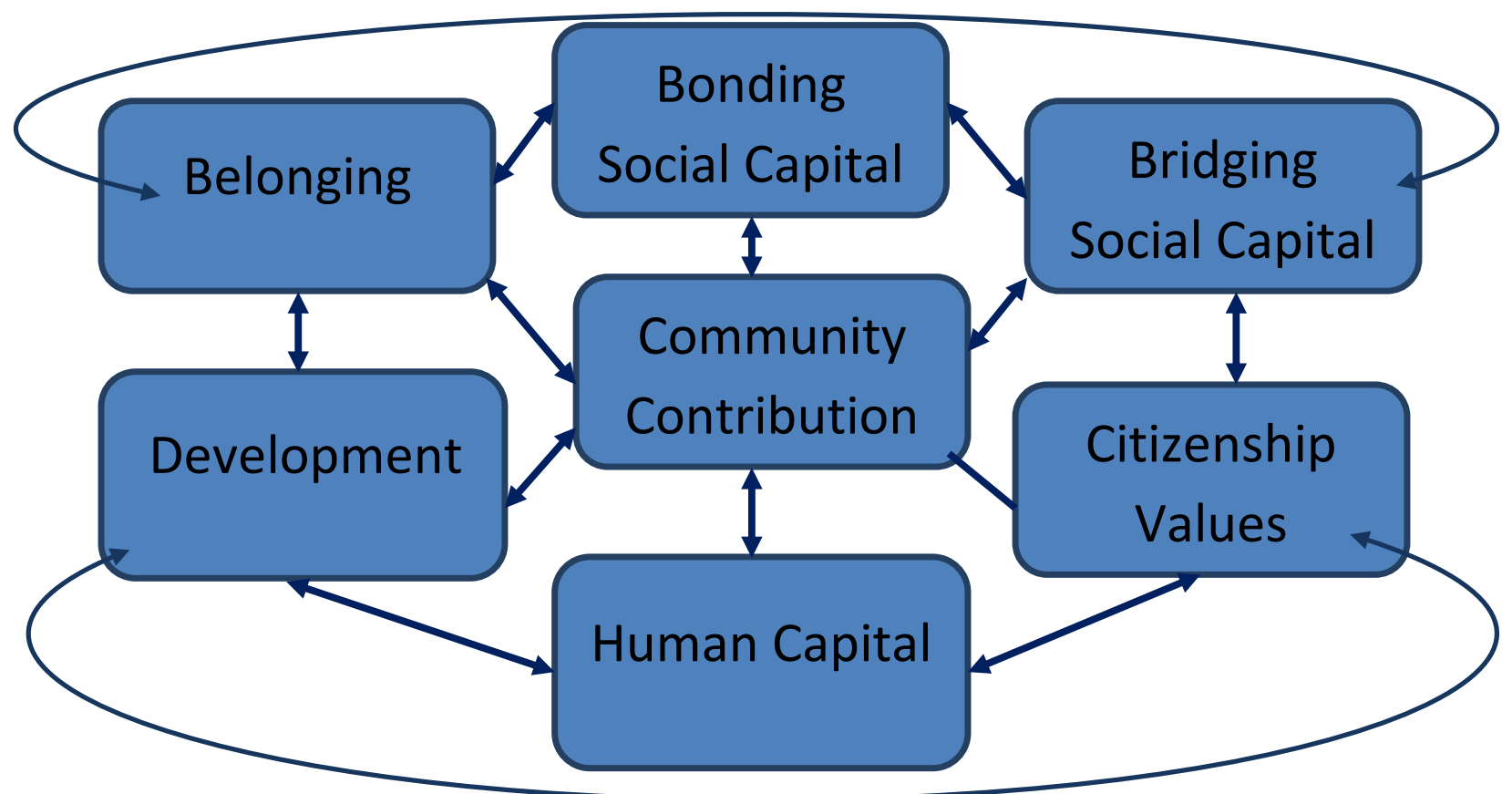

While this paper specifically focussed on Surf Life Saving as an organisation in Australia, we are interested in examining the potential of using this case to develop a broader measure of social impact. The challenge here is to develop a measure that is more than a micro evaluation tool for a specific program, and less than a global measure of community wellbeing. We are seeking a tool that focuses on the local community, and the social impact that a community organisation or group can make to the broad well-being of that community. In this project, we are seeking to identify a number of criteria, drawn in the first instance from surf life saving clubs, but criteria that may have a broad relevance to ANY local community group, including for instance, local church congregations, other sports clubs, service clubs, or smaller self help support groups. 
While part of the social impact demonstrated within this model relates to social capital, nonetheless social impact, at this meso level, is broader than the concept of social capital would imply. Of equal relevance is the concept of personal development, and human capital. All of these have clear social benefits beyond the immediate organisation. It is likely that the initial construction of club identity and the supportive bonding relationships within the organisation are crucial for the subsequent development of social and human capital in the broader sense. We conceptualise social capital in the first instance as a resource, developed within the community organisation in the form of bonding social capital, which is then available to use as a tool in creating wider social impact outside the organisation. To the extent that the organisation does create a positive social contribution to the local community, then it will serve to increase the stock of human and social capital more generally throughout the community in question. However it is also likely that these factors do not form a linear progression (as suggested by the model) but rather are mutually interdependent, suggesting that there is likely to be a reciprocal feedback effect of each factor on the others. Therefore the sum of the parts cannot predict the whole due to the non-linear system dynamic. But studying locally situated interactions may provide insight into how the micro level builds meaningful interactions between individuals and groups within communities.

Each of these factors is in principle measurable, and their inter-relationships empirically demonstrated. These results are consistent with recent data coming out of the UK, for example the study by Kay and Bradbury (2009) found similar outcomes for a youth volunteering in sport program. However it also clear from the present study (and others) that only social measures of social impact can accurately reflect the real and positive contribution that organisations and programs such as this can provide for the wider community and for long term benefits to its members. It may be possible to estimate the dollar value of some generic outcomes of the social impact process, but any monetised indicator will inevitably understate the true social value of the process.

One important question concerns the reach of these criteria. Do those identified as generic here actually apply to all other organisations, or only some types of community organisations? Are there other dimensions of social impact not tapped within SLS but which are nonetheless important in other contexts? For example some organisations may generate a deep sense of learning about life and death, whereas others may be concerned with a much 
more superficial sense of pleasure. We don't have the answers to these questions yet. What we have done is identify a set of criteria for the measurement of social impact in the local community, which may provide a useful starting point in the development of a generic measure. Secondly we have established a research agenda, one which will gradually serve to explore the reach of social impact(s) of different kinds of community organisations in different contexts. In doing so, it should be possible to create a broader understanding of the social contribution made by such organisations to the larger well being of the local community.

\section{Acknowledgements}

The team has worked closely with Shauna Sherker and others at the Surf Life Saving Association of Australia. This work was made possible through a UTS Partnership grant (2010)

\section{References}

ABS 2006, Voluntary Work Australia. Cat No: 4441.0

Allen 2005, Valuing an Australian Icon: The Economic and Social Contribution of Surf Lifesaving in Australia, Report to Surf Life Saving Australia Limited October 2005, The Allen Consulting Group Pty Ltd.

Carman, J. 2007, 'Evaluation practice among community-based organisations: Research into the reality', American Journal of Evaluation, vol.28, no.1, pp. 60-75.

Giovannini, E., Hall, J., Morrone, A., and Ranuzzi, G. 2009, A Framework to measure the Progress of Societies. Draft OECD working Paper, OECD.

Halpern, D. 2005, Social Capital, Polity Press, Cambridge.

Kay, T. and Bradbury, S. 2009, 'Youth sport volunteering: developing social capital?', Sport, Education and Society, vol.14, no.1, pp. 121-140.

Leonard, R. and Onyx, J. 2003, 'Networking through loose and strong Ties: an Australian qualitative study, Voluntas, vol. 14,no.2, pp. 189-204.

Matthews, B. 2006, Life Saving Victoria: Volunteer Member Retention Analysis, Life Saving Victoria.

National Compact 2010, Vision Purpose and Principles. http://www.nationalcompact.gov.au/ resources/vision-purpose-and-principles/ (Last accessed $16^{\text {th }}$ May, 2010)

Onyx, J. and Bullen, P. 2000, 'Measuring social capital in five communities', Journal of Applied Behavioral Science, vol.36, no. 1, pp.23-42.

Onyx, J., Edwards, M., and Bullen, P. 2007, 'The intersection of social capital and power: an application to rural communities, Rural Society (special issue) vol.17, no.3, pp.215-230.

Partridge, E., and West, S. 2010, Community Indicator Framework, Final Report. Institute for Sustainable Futures, UTS and McCauley Centre, Uni of Melbourne. 
Productivity Commission 2010, Contribution of the Not-for-Profit Sector, Research Report, Canberra

Putnam, R. 1993, Making Democracy Work: Civic Traditions in Modern Italy, Princeton University Press, Princeton, N.J.

Putnam, R. 2000, Bowling Alone: The Collapse and Revival of American Community, Simon and Schuster, New York.

SLS (2009), Surf Life Saving Australia Annual Report 2008-2009, Surf Life Saving Australia, Bondi Beach, NSW

Wiseman, J., Heine, W., Langworthy, A., McClean, N., Pyke, J., Raysmith, H., and Salvaris, M. 2006, Measuring wellbeing, engaging communities: Developing a community indicators framework for Victoria. http://www.communityindicators.net.au/files /civ/20060817_VCIP_Final_Report.pdf

Woolcock, M. 2001, The place of social capital in understanding social and economic outcomes. Development Research Group, The World Bank, and Kennedy School of Government, Harvard University.

Woolcock, M. and Narayan, D 2000, 'Social capital: Implications for development theory, research and policy’, World Bank Research Observer, vol.15, no.2, pp. 225-250.

Zappalà, G., and Lyons, M. 2009, Recent approaches to measuring social impact in the third sector: an Overview. CSI Background Paper No. 5, Centre for Social Impact, University of NSW. 